\title{
Achtergronden bij de Richtlijn simulatie teamtraining
}

\section{Inleiding en context}

Na verschijning van het rapport To Err is Human in 2000, waarin op vermijdbare fouten en incidenten in de gezondheidszorg wordtewezen, is het besef gerezen dat de gezondheidszorg betrouwbaarder en veiliger moet worden. ${ }^{8}$ In bovengenoemd rapport is hiervoor reeds een aantal aanbevelingen gedaan, zoals invoering van een meldsysteem voor medische incidenten en fouten, van gesloten veiligheidssystemen en kwaliteitsstandaarden voor professionals werkzaam in de gezondheidszorg. Het rapport geeft verder aan dat er meer aandacht moet zijn voor het verbeteren van prestaties van teams, bijvoorbeeld door middel van training van multidisciplinaire teams, dat wil zeggen teams bestaande uit zowel medisch specialisten als verpleegkundigen en ander ondersteunend personeel, waarbij de training plaatsvindt in een gesimuleerde omgeving. ${ }^{8}$

Dit idee om multidisciplinaire teams te trainen en deze zo beter voor te bereiden op complexe taken op de werkvloer, is niet nieuw. De luchtvaart heeft ruim 30 jaar ervaring met het trainen van teams middels het zogenaamde Crew Resource Management (CRM). Onderzoek naar de effectiviteit van deze trainingen geeft aan dat communicatie tussen teamleden wordt verbeterd, handelingen beter worden gecoördineerd, het beslisproces beter verloopt en dat fouten en incidenten beter worden gemanaged. ${ }^{9}$ Deze resultaten blijken bij zeer diverse teams bereikt te worden, zowel in vliegende teams als in teams van medewerkers aan de grond. In navol- ging van de training in de luchtvaart hebben dan ook andere sectoren, zoals het leger en de marine, succesvol trainingsprogramma's geïmplementeerd en ook in de gezondheidszorg worden vandaag de dag teams getraind. ${ }^{10-13}$ De hoop en verwachting is dat deze medische teamtrainingsprogramma's tot een verbetering zullen leiden van de kwaliteit van zorgverlening. ${ }^{14}$

\section{Waarom teamtraining?}

Er is vrij veel onderzoek gedaan naar het functioneren van teams. ${ }^{14}$ Daaruit is bijvoorbeeld gebleken dat teams minder fouten maken dan individuen. ${ }^{3} 9$ Onderzoek in de luchtvaart laat zien dat teams die een aantal dagen samenwerkten, significant minder fouten maakten, terwijl individuele teamleden wel sneller fouten maakten door onder andere de opgetreden vermoeidheid. ${ }^{15}$ Dat er uiteindelijk minder fouten gemaakt werden, valt toe te schrijven aan teamkenmerken, zoals het herkennen en erkennen van fouten van anderen, coördinatie van het werk en het compenseren voor elkaar. Ook kunnen teams het stressniveau juist verlagen, waardoor opgetreden vermoeidheid minder vaak tot fouten leidt. Bovendien lijkt zelfs een slecht team beter te presteren dan geen team. ${ }^{15}$

Ook in medisch onderzoek zijn aanwijzingen te vinden dat het goed functioneren van teams een belangrijke rol speelt in het verzekeren van de veiligheid van patiënten en in het voorkomen van fouten en incidenten. ${ }^{16}$ Het goed laten functioneren van een team gaat echter niet vanzelf. 
Een groep van experts samen laten werken geeft nog geen garantie voor een expertteam. ${ }^{2}$ Dit probleem geldt zeker ook voor de gezondheidszorg. De dagelijkse praktijk in een ziekenhuis wordt gekenmerkt door multidisciplinaire teams van steeds wisselende samenstelling. Medische professionals worden van oudsher echter individueel opgeleid en zijn zodoende ook niet voorbereid op de eisen die het werken in een multidisciplinair team aan hen stelt. ${ }^{14}{ }^{17-18} \mathrm{Er}$ is dus een noodzaak om alsnog aan deze teamvaardigheden te werken.

Teamwork kan op meerdere manieren worden bevorderd. Dit kan bijvoorbeeld door het samenstellen van teams uit medewerkers die de juiste kennis, vaardigheden en attituden hebben voor een goede samenwerking. Een tweede manier is het aanpassen van de werkomgeving op teamwork, bijvoorbeeld door taken en werkstructuren beter aan te passen op deze teams. ${ }^{14}$ De derde en meest toegepaste methode is het trainen van gehele teams, om hen zo beter voor te bereiden op het effectief samenwerken. ${ }^{14} 19$

Teamtraining vormt de basismethode voor deze Richtlijn en kan worden gedefinieerd als 'het toepassen van een set instructionele strategieën, die een beroep doen op onderwijsinstrumenten, zoals simulatoren, lesmateriaal, video's etc'. ${ }^{20}$ Een effectieve teamtraining bevat bovendien algemene principes uit leertheorieën, geeft informatie over de benodigde teamvaardigheden, creëert mogelijkheden om vaardigheden te oefenen en zorgt voor remediërende feedback. ${ }^{14}$

\section{Teamwork en teamvaardigheden}

Het is in de gezondheidszorg niet voldoende om vaardig te zijn in alleen de eigen individuele taken; men moet ook goed teamwork leveren. Wat is goed teamwork dan precies? Teamwork bestaat volgens Baker et al. uit 'een samenhangende set van kennis, vaardigheden en attitudes, die ervoor zorgen dat prestaties gecoördineerd en aangepast aan specifieke situaties uitgevoerd kunnen worden'. ${ }^{21}$ Onafhankelijk van het gegeven of een team lang of kort samenwerkt, wanneer zij dezelfde set aan teamvaardigheden nastreeft, zal het team als geheel beter presteren dan wanneer dit niet het geval is. ${ }^{14} 22 \mathrm{Bij}$ deze set horen bijvoorbeeld het monitoren van het presteren van anderen, kennis over eigen verantwoordelijkheden en die van andere teamleden maar ook een positieve houding ten opzichte van het werken in teams. ${ }^{14}$

Recent zijn in verschillende medische specialismen zogenaamde teamvaardigheden geïdentificeerd, die een voorwaarde vormen voor effectief teamwork. Zo is voor de Anesthesiologie de Anesthesia Crisis Resource Management (ACRM) ontwikkeld. ${ }^{23}$ Teamvaardigheden van multidisciplinaire teams, bestaande uit anesthesiologen, overige artsen, verpleegkundigen, technici en andere medische professionals, worden daar getraind in een gesimuleerde omgeving. Daarbij worden in scenario-oefeningen verschillende vaardigheden aangesproken, zoals onderzoeken, aannames formuleren, communiceren tussen teamleden, geven en ontvangen van feedback, leiderschap uitoefenen, onderhouden van een positief groepsklimaat en het herevalueren van handelingen. Gaba et al. zijn hier ook mee aan de slag gegaan. ${ }^{24}$ Gaba heeft CRM uit de luchtvaart als voorbeeld genomen en heeft 15 CRM principes opgesteld voor teamtrainingen in anesthesie. Healy, Undre en Vincent hebben de Observational Assessment for Teamwork in Surgery (OTAS) ontwikkeld, voor het beoordelen van teamvaardigheden als samenwerking, leiderschap, coördinatie, omgevingsbewustzijn en communicatie binnen chirur- 
gische teams. ${ }^{25}$ Ook andere disciplines, zoals Acute geneeskunde en Neonatologie hebben cruciale elementen van teamwork geïdentificeerd en verwerkt in een set teamvaardigheden. ${ }^{2} 26$

Andere auteurs pakken de teamvaardigheden minder disciplinespecifiek aan. Chakraborti et al. hebben acht algemene principes geïdentificeerd, welke afgeleid zijn van wat Baker et al. onder benodigde kennis, vaardigheden en attituden scharen. ${ }^{17}$ Deze vaardigheden of principes zijn: leiderschap, back-up gedrag, het monitoren van elkaars prestaties, communicatie, aanpassingsvermogen, het hebben van gedeelde mentale modellen, wederzijds vertrouwen en het gericht zijn op het team. Burke et al. hebben het ook wel over de 'big five' van teamwork. ${ }^{11} \mathrm{Zij}$ onderscheiden leiderschap, het monitoren van elkaars gedrag, back-up gedrag, aanpassingsvermogen of flexibiliteit en collectieve oriëntatie van het team als cruciale teamcompetenties. Een team- of taakanalyse zou daarbij de doorslag moeten geven welke teamcompetenties tijdens een specifieke training aan bod zouden moeten komen. ${ }^{11} 16$

Ook al heeft ieder specialisme haar eigen benamingen - wat de een bijvoorbeeld informatie delen noemt, schaart de ander onder communicatie - toch komen de omschrijvingen vrij vaak overeen. ${ }^{14} 26$ Het lijkt dus niet zo belangrijk welke indeling men precies kiest voor de teamvaardigheden, als maar duidelijk is wat er precies onder verstaan wordt.

\section{Technische en niet-technische vaardigheden}

Er bestaat in de literatuur ook een andere manier om deze teamvaardigheden aan te spreken. Hiertoe maakt men het onderscheid tussen Technical Skills (technische vaardigheden) en Non-Technical Skills (niet-technische vaardigheden). ${ }^{2}$ 27-28 Onder technische vaardighe- den worden alle medische handelingen verstaan. Hiervoor is in de regel in de vervolgopleidingen voldoende aandacht. $\mathrm{Bij}$ niet-technische vaardigheden gaat het om het handelen dat niet direct gerelateerd is aan medische expertise, medicijnen of uitrusting. ${ }^{2}$ Deze non-technical skills zijn ook afgeleid van CRM uit de luchtvaart en worden daar omschreven als cognitieve en sociale vaardigheden die een cruciale rol spelen in de veiligheid, vooral in individuen die in teams werken in organisaties met hoge veiligheidsrisico's. ${ }^{27}$ Het gaat hierbij om interpersoonlijke vaardigheden als communicatie, samenwerking en leiderschap en om cognitieve vaardigheden als omgevingsbewustzijn (situation awareness) en beslisvaardigheid.

Bij het opstellen van de Richtlijn simulatie teamtraining is uitgegaan van de indeling in technisch en niet-technische vaardigheden. Hiervoor is ook gekeken naar drie bestaande modellen voor de beoordeling van non-technical skills. Het eerste is de Ottawa Global Rating Scale, de tweede is de Anaesthetists' Non-Technical Skills (ANTS) en het derde is het model voor de Non-Technical Skills for Surgeons (NOTSS). Deze zijn samengebracht in Tabel 1.

- De Ottawa Global Rating Scale beschrijft vijf niet-technische vaardigheden, namelijk leadership, problem solving, situational awareness, resource utilization en communication. ${ }^{1}$ Deze vijf niet-technische vaardigheden worden elk geoperationaliseerd in drie criteria. In Tabel 1 is te zien dat de Ottowa Global Rating Scale overlap heeft met de andere twee modellen, maar gebruik maakt van enkele afwijkende benamingen voor de vaardigheden.

- Het ANTS systeembeschrijft de niet-technische vaardigheden op drie niveaus. ${ }^{2}$ 
Tabel 1. Niet-technische vaardigheden.

\begin{tabular}{|c|c|c|}
\hline Teamcompetenties & Opgenomen in & Voorbeelden van operationalisaties \\
\hline Taskmanagement & $\begin{array}{l}\text { ANTS } \\
\text { NOTSS }\end{array}$ & $\begin{array}{l}\text { Planning/voorbereiding } \\
\text { Organisatie } \\
\text { Reactie op veranderingen } \\
\text { Prioriteiten stellen } \\
\text { Middelen }\end{array}$ \\
\hline Teamwork & $\begin{array}{l}\text { ANTS } \\
\text { NOTSS }\end{array}$ & $\begin{array}{l}\text { Coördineren van activiteiten van het team } \\
\text { Uitwisselen van informatie } \\
\text { Gedeelde kennis en begrip van de situatie }\end{array}$ \\
\hline Situation awareness & $\begin{array}{l}\text { Ottawa Global Rating Scale } \\
\text { ANTS } \\
\text { NOTSS }\end{array}$ & $\begin{array}{l}\text { Informatie verzamelen } \\
\text { Informatie herkennen en begrijpen } \\
\text { Anticiperen }\end{array}$ \\
\hline Decision making & $\begin{array}{l}\text { ANTS } \\
\text { NOTSS }\end{array}$ & $\begin{array}{l}\text { Opties overwegen } \\
\text { Opties kiezen en communiceren } \\
\text { Besluiten doorvoeren en evalueren }\end{array}$ \\
\hline Leadership & $\begin{array}{l}\text { Ottowa Global Rating Scale } \\
\text { NOTSS }\end{array}$ & $\begin{array}{l}\text { Aansturen van teamleden } \\
\text { Sturen van handelingen } \\
\text { Steun/support van anderen } \\
\text { Omgaan met stress }\end{array}$ \\
\hline Communication & $\begin{array}{l}\text { Ottowa Global Rating Scale } \\
\text { NOTSS (valt onder teamwork } \\
\& \text { communcation) }\end{array}$ & $\begin{array}{l}\text { Helder en beknopt communiceren } \\
\text { Gebruiken van directe verbale en non-verbale } \\
\text { communicatie } \\
\text { Luisteren naar teaminput }\end{array}$ \\
\hline Resource utilization & Ottowa Global Rating Scale & $\begin{array}{l}\text { Passend om hulp vragen } \\
\text { Passend gebruik van middelen } \\
\text { Passende taakprioritisering }\end{array}$ \\
\hline Problem solving & Ottowa Global Rating Scale & $\begin{array}{l}\text { Efficiënt problemen oplossen (ABC-methode) } \\
\text { Snelle implementatie } \\
\text { Overwegen van alternatieven }\end{array}$ \\
\hline
\end{tabular}

Er worden vier categorieën aan vaardigheden beschreven. Op het tweede niveau worden bij deze vier categorieën drie tot vijf operationalisaties beschreven die onder deze vaardigheid vallen. Op het derde niveau wordt bij ieder element een voorbeeld van goed en slecht gedrag gegeven waaraan men kan den- ken bij dit element, zodat de abstracte termen worden geconcretiseerd.

- Het NOTSS systeem kent net als de Ottowa CRM Checklist en het ANTS systeem categorieën en elementen. ${ }^{3}$ Bij de elementen horen ook observeerbare gedragingen, de zogenaamde markers genoemd. Verschil met de andere twee in- 
delingen is dat de NOTSS systeem vijf categorieën kent.

Naast deze systemen heeft Baggs in 1994 een concreet uitgewerkte vragenlijst ontworpen voor samenwerken en besluitvorming, het CSACD (Collaboration and Satisfaction About Care Decisions). ${ }^{29}$ Deze vragenlijst heeft betrekking op de laatste categorie in het NOTSS systeem: communicatie \& teamwork. Er wordt onder andere gericht gevraagd naar de mate waarin ieders overwegingen betrokken werden bij de besluitvorming, in welke mate de besluitvorming werd gecoördineerd en in welke mate er overlegd werd tussen verpleging en artsen over de behandeling.

In de Richtlijn simulatie teamtraining is men uitgegaan van de indeling volgens de Ottowa Global Rating Scale. De Ottawa Global Rating Scale heeft leiderschap, evenals de NOTSS, als een aparte teamcompetentie opgenomen in haar omschrijving van teamcompetenties, in tegenstelling tot de ANTS. Een goed team heeft echter ook een goede leider nodig. Doorgaans zijn medisch specialisten leider van het multidisciplinaire team. Zij worden hier in hun opleiding vaak onvoldoende op voorbereid. ${ }^{15}$ De huidige werkstructuren vragen om goede leiders. Goede leiders zorgen voor een groepsgevoel, kunnen in een gezamenlijk doel voorzien en kunnen groepsleden inspireren en helpen in hun taken. Slechte leiders kunnen ook leiden tot onzekere situaties en meer stress en daardoor leiden tot meer fouten in het handelen van teams. ${ }^{15}$ Vandaar dat leiderschap ook een plek verdient in de teamcompetenties. Wel is de omschrijving van de NOTSS bij 'task management' enigszins uitgebreid naar de verdeling zoals deze in de ANTS staat, doordat deze vollediger is.

Kim et al. hebben het gebruik van een globale beoordelingslijst vergeleken met een gespecificeerde checklist. ${ }^{1}$ Vooralsnog zijn geen verschillen in betrouwbaarheid aangetoond; gebruikers hadden wel een lichte voorkeur voor de globale lijst omdat dit gemakkelijker was in gebruik en zich meer leende voor formatieve beoordeling.

Als hulpmiddel in het verbeteren van communicatiestromen tussen verschillende hulpverleners is in Amerika het instrument SBAR ontwikkeld. ${ }^{30}$ Het overdragen van informatie volgens de SBARmethode zorgt voor een adequate, eenduidige en heldere communicatie. SBAR staat voor Situation (situatie), Background (achtergrond), Assessment (beoordeling) en Recommendation (aanbeveling). Een voorbeeld van een SBAR-checklist is te zien in Bijlage 6. Een hulpmiddel dat veelvuldig gebruikt wordt bij behandelingen ter controle van essentiële aspecten is de Time-out procedure. Hierin wordt voorafgaand aan de behandeling geverifieerd of alle aspecten die relevant zijn, kloppen. 'Hebben we te maken met de juiste patiënt?' en 'voeren we de juiste behandeling uit?' zijn vragen die onder de Time-out procedure vallen. Dit alles om de patiëntveiligheid te verbeteren en medische fouten te voorkomen.

\section{Relatie tot de CanMEDS competenties}

Binnen het medisch onderwijs wordt steeds meer gedacht in competenties. Voor de medische vervolgopleiding tot specialist zijn daarvoor in Nederland de CanMEDS competenties overgenomen vanuit Canada. Deze zeven CanMEDS competentiegebieden zijn: medisch handelen, communicatie, samenwerking, kennis en wetenschap, maatschappelijk handelen, organisatievaardigheden en professionaliteit. ${ }^{5-6} 31$

Het trainen van teamvaardigheden past in het huidige competentiedenken. Teamtraining heeft als doel om teams, door het trainen van teamvaardigheden, voor te 
bereiden op hun rol in de praktijk, net als het trainen van de CanMEDS competenties jonge artsen moet voorbereiden op hun taak in de praktijk. De CanMEDS competenties kunnen dan ook gezien worden als individuele competenties, tegenover de teamcompetenties die getraind worden in teamtrainingen.

Bij een studie naar instrumenten voor evaluatie van CanMEDS competenties bij artsen in opleiding, blijkt dat simulaties ook regelmatig worden gebruikt voor de beoordeling van deze competenties. ${ }^{32}$ Met name de competenties medisch handelen, communicatie, samenwerking en organisatievaardigheden worden mede beoordeeld middels simulaties. Dit lijkt goed aan te sluiten op de teamcompetenties die worden getraind in een simulatie teamtraining. Medisch handelen sluit daarbij aan bij de technische vaardigheden en de overige drie bij de niet-technische vaardigheden.

\section{Type teamtrainingen}

Gedurende de laatste paar jaren zijn in de medische wereld verschillende soorten teamtrainingsprogramma's ontwikkeld. ${ }^{33}$ Sommige van deze programma's maken gebruik van simulatoren en realistische simulatieomgevingen, terwijl andere programma's met veel minder geavanceerde technieken werken en zich voornamelijk baseren op traditionele lesmethoden. Deze laatste groep programma's richt zich vooral op het proces van bewustwording en maakt daarbij bijvoorbeeld gebruik van studiemateriaal, videodemonstraties, rollenspellen etc. ${ }^{33}$ Er wordt echter in toenemende mate gebruik gemaakt van simulaties in trainingsprogramma's.

Simulaties kunnen ingedeeld worden aan de hand van hun 'fidelity', dat wil zeggen de mate waarin ze de werkelijkheid benaderen. ${ }^{34}$ Men kan hierbij zowel naar de gebruikte systemen kijken, dus hoeveel lijkt een gesimuleerde patiënt of omgeving op de werkelijke patiënt of werkomgeving, maar ook naar de functionele gelijkheid, in hoeverre de benodigde set teamvaardigheden in de gesimuleerde taak is ingebed. ${ }^{35}$ Doorgaans wordt in de medische wereld onder 'fidelity' verstaan de mate waarin de simulatoren de werkelijkheid benaderen.

Motorische basisvaardigheden kunnen op deeltaaksimulatoren worden geoefend. Ook computersimulatoren en 'virtual reality' omgevingen kunnen gebruikt worden voor het oefenen van zulke deelvaardigheden. Hier spreekt men doorgaans van 'low-fidelity' systemen.

Uit onderzoek blijkt dat simulatieonderwijs vaak effectiever is dan andere onderwijsmethoden zoals 'problem-based learning. ${ }^{36}$ De Richtlijn gaat dan ook uit van simulatie teamtrainingen. Hierbij wordt uitgegaan van 'high-fidelity' simulaties. Er wordt gebruik gemaakt van simulatiepatiënten. Dit kunnen echte personen zijn of geavanceerde simulatoren. Ook de werkomgeving is gesimuleerd, oftewel in een speciaal ingerichte simulatieruimte, die voorzien is van alle apparatuur en middelen, welke ook in de praktijk terug te vinden zijn, oftewel door training in de praktijkruimten zelf. Juist het trainen op een gesimuleerde werkplek, waar multidisciplinaire teams net als in een praktijksituatie samenwerken, leidt tot een krachtige leerervaring en stelt teamleden in staat op hun rol binnen een team te reflecteren. ${ }^{37}$ Met behulp van simulatieonderwijs kunnen zodoende technische en niet-technische medische vaardigheden samen en in een veilige omgeving worden getraind. ${ }^{33}$

Sommige trainingen maken gebruik van video opnamen als basis voor de debriefing, zoals de zogenaamde Video Assisted Realtime Simulation (VARS) training. Bij een VARS worden de parameters, 
zoals bloeddruk, frequentie van de hartslag en ademfrequentie, via een computer gesimuleerd en geprojecteerd op een echte patiëntenmonitor. Ook wordt via een gelijktijdige stream het team in actie middels twee camera's opgenomen. Deze opname wordt direct na de training, in de debriefing, besproken.

\section{Richtlijnen}

Er bestaan al enkele richtlijnen voor het ontwikkelen en het uitvoeren van simulatie teamtrainingen. ${ }^{11} 13 \quad 38-39 \quad 53$ Deze richtlijnen zijn deels gebaseerd op wetenschappelijk onderzoek en op onderwijskundig bekende en effectieve trainingstechnieken, maar zijn ook wel gebaseerd op 'learning by doing' van de makers en op lokale ervaringen met teamtrainingsprogramma's.

Ontworpen trainingen zijn contextspecifiek. Dat wil zeggen dat elke training een eigen context, doelstellingen, onderwerp en doelgroep heeft, waarop de training aangepast is of zal moeten worden. ${ }^{40}$ De bestaande richtlijnen hebben alle hun eigen niveau van abstractie en zijn in meer of mindere mate toegespitst op een specifieke trainingssituatie, op specifieke deelnemers en met specifieke doelstellingen. Daarnaast hangt de opzet en de inhoud van een richtlijn voor een groot deel af van keuzes die instructeurs en ontwerpers maken. Natuurlijk zijn er in de richtlijnen wel een aantal algemeen geldende principes te identificeren. In deze paragraaf zullen een aantal voorbeelden weergegeven worden van de opzet van teamtrainingen. Daarbij zijn vaak terugkerende principes geïdentificeerd, die ook gebruikt zijn in de Richtlijn simulatie teamtraining.

In de literatuur wordt bij de opzet van trainingen soms een opdeling gemaakt in drie delen. ${ }^{11} 13$ 38-39 Deze driedeling is niet bij elke richtlijn precies hetzelfde, maar komt grofweg met de volgende indeling overeen. Een training begint eigenlijk al ver voor de training zelf, bijvoorbeeld met het bepalen van de leerdoelen, inhouden en opzet voor de simulatietraining. ${ }^{11}$ Een training zelf begint met het openen en inleiden van het scenario. Er is tijd voor het controleren van de materialen, en voor het voorbespreken. Hierin moeten een aantal dingen uiteengezet worden, bijvoorbeeld de verhouding van de training tot het onderwijsprogramma, de rol van de participanten, de omgeving waarin de simulatie zich afspeelt, persoonlijke leerdoelen van de participanten en leerdoelen met betrekking tot het team. Tenslotte moet duidelijk zijn dat het om een leersituatie gaat en niet om een assessment.

Het tweede deel van de training bestaat uit de simulatie en de nabespreking. Het scenario wordt gespeeld door de participanten. De duur van het scenario kan wisselen, naar gelang het onderwerp van de training, maar deze scenario's worden doorgaans real-time gespeeld. ${ }^{38}$ In sommige richtlijnen wordt ook verwezen naar het opnemen van de trainingssessies, zodat deze opnamen gebruikt kunnen worden voor de nabepreking. ${ }^{39}$ Er kan worden gevraagd aan de participanten om hardop te denken, zodat men meer inzicht heeft in de beweegredenen voor het handelen van de participant. ${ }^{38} \mathrm{Na}$ het doorlopen van het scenario volgt de nabespreking, de zogenaamde debriefing. Deze debriefing heeft een belangrijke functie in de simulatie teamtraining. Vandaar dat een aparte paragraaf is gewijd aan de debriefing.

Het derde en laatste deel van de training bestaat uit de afsluiting. Sommige richtlijnen vinden juist dat de debriefing bij het derde deel hoort. ${ }^{13}$ Een afsluiting bestaat onder andere uit een samenvatting van de resultaten, gerelateerd aan de leerdoelen. ${ }^{39}$ Er kunnen ook voornemens 
Tabel 2. Richtlijnen voor een effectieve training. ${ }^{11}$

\section{Setting the stage:}

1. Het ontwerp en de ontwikkeling van een teamtraining moet worden geleid door een analyse van het werk/de taken van een team.

2. Wanneer er weinig tijd voor training zelf is, kunnen er middelen worden ingezet om van te voren te oefenen, zodat de impact van de training zelf wordt gemaximaliseerd.

3. Verzeker dat informele boodschappen over het belang van de teamtraining gelijk zijn aan de uitgesproken, formele berichtgeving.

\section{Ontwerp/implementatie:}

4. Teamtraining legt de nadruk op de belangrijkste componenten van teamwork.

5. Zorg ervoor dat de ontworpen training een gemeenschappelijk begrip faciliteert.

6. Er wordt een beroep gedaan op (aan)gepast gedrag.

7. De training stimuleert gedrag en houdingen die passen bij een lerend werkklimaat.

8. Zorg voor een gesloten communicatiecirkel.

9. Zorg dat de training systematisch kansen biedt voor het oefenen van de benodigde team competenties.

\section{Post training:}

10. Evalueer de teamtraining en verzamel verschillende soorten bewijs over haar impact.

worden geformuleerd. De training kan daarnaast nog worden geëvalueerd, bijvoorbeeld door middel van een enquête onder de participanten. ${ }^{11} 38$

Naast de indeling in drie onderdelen, wordt ook vaak gekozen voor lijstjes met tips en aanbevelingen voor het opzetten en laten slagen van een simulatie teamtraining. ${ }^{11}{ }^{41}$ In Tabel 3 is een voorbeeld weergegeven van zo'n lijstje.

De praktische richtlijn kent ook de indeling volgens drie delen en is vormgegeven als een lijst met aanbevelingen en aandachtspunten voor het ontwerpen en geven van trainingen.

\section{Scenario's}

Sommige onderzoekers besteden extra aandacht aan het ontwerpen van de scenario's. Zo beschrijven Bush et al. een systematisch raamwerk voor het ontwerpen van meerdere scenario's, waarin op dezelfde wijze de teamcompetenties getest worden (zie Tabel 3). ${ }^{42}$
Tot nu toe worden scenario's uit simulatie trainingen meestal ontleend aan echte klinische scenario's. Dit maakt deze scenario's inherent realistisch, maar niet per definitie meer geschikt om opgenomen te worden in een leerlijn of om gerichter mee te werken aan teamcompetenties. Het voordeel van een zelf gekozen of ontworpen en gelijkwaardige set scenario's is dat het makkelijker is om gedragsveranderingen te meten na training. De scenario's kunnen bovendien ontworpen worden op basis van de gewenste teamvaardigheden die verbeterd moeten worden, waardoor het makkelijker is een debriefing te leiden en uiteindelijk een doorgaande leerlijn te ontwerpen. ${ }^{42-43}$

\section{De debriefing}

Feedback heeft positieve effecten op het handelen van teamleden. ${ }^{44}$ De nabespreking van het scenario vormt dan ook een belangrijk en mogelijk zelfs het belangrijkste onderdeel van de simulatie. ${ }^{45}$ On- 
Tabel 3. Methodologie voor het ontwerpen van een set van scenario's. ${ }^{42}$

\section{Geldend voor alle scenario's in een serie: het Algoritme}

1. Stel een multidisciplinair ontwikkelteam samen

- bepaal hoeveel scenario's er ontwikkeld moeten worden,

- bepaal welk scoringssysteem (de teamcompetenties) er gebruikt gaan worden.

2. Bedenk bij het bepalen van de kenmerken van de patiënt wie er deelnemen aan de simulatie

- wie worden er getraind en geëvalueerd,

- wat is de achtergrond en het expertiseniveau van de deelnemers,

- bepaal leeftijd en gewicht voor de simulator,

- bepaal de startconditie (vital signs, bewustzijnsniveau, etc.).

3. Kies een gebeurtenis

- kies bij voorkeer een enkele, simpele pathofysiologische reactie, om minder nadruk te leggen op technische vaardigheden en klinische expertise (bijvoorbeeld hypoxie).

4. Bepaal wat het verloop en de ontwikkeling in het scenario zal zijn

- wie zijn/worden betrokken bij het scenario vanaf het begin,

- zijn er anderen beschikbaar om te helpen, of juist niet,

- hoe verslechtert de toestand van de patiënt,

- wat is het eindpunt (bijvoorbeeld: als de medicatiefout wordt hersteld of de luchtweg vrijgemaakt is),

- programmeer fysiologie van de simulator voor het betreffende scenario.

\section{Uniek voor elk specifiek scenario}

5. Beschrijf de gebeurtenissen voorafgaand aan de komst van de deelnemer(s)

- zorg dat elk scenario zijn eigen verhaal heeft.

6. Selecteer de setting.

- kies herkenbare omgevingen en vermijd locaties die niet bekend zijn voor de deelnemers

- varieer de setting om elk scenario nieuw te laten lijken.,

7. Bepaal de 'afleiders'

- geef specifieke rollen/opdrachten (bijvoorbeeld wel of niet behulpzaam zijn),

- zorg voor materiaalproblemen (bijvoorbeeld afwezige apparatuur of slecht functionerende apparatuur),

- creëer afleidingen door geluid of ruimteverandering (bijvoorbeeld door bedekken van patiënt of deze vreemd neer te leggen).

8. Zorg dat de juiste middelen wel voorhanden zijn

- zorg voor werkende instrumenten wanneer de deelnemers slecht werkende instrumenten identificeren.

9. Schrijf een script voor de acteurs

- includeer 'cues' waarop gereageerd mag worden en specifieke afleidende gedragingen,

- zorg voor een draadloze communicatie (headset) met acteurs,

- zorg voor training en oefen de doorloop van een scenario. 
derzoek toont aan dat juist het nabespreken een grote toegevoegde waarde geeft aan het leerrendement, doordat door het debriefen actief wordt geleerd en verandering wordt gefaciliteerd. ${ }^{37} 46-47$ Onder actief leren wordt verstaan dat men zowel lichamelijk als geestelijk actief bezig is. Simulatietraining bestaat voor een deel uit handelen en voor een ander deel uit reflecteren op dit handelen in de debriefing. Dit past bij Schön's theorie van de 'Reflective Practice' en zodoende bij erkende onderwijskundige principes. ${ }^{48}$ Schön geeft in deze theorie het belang aan van zowel 'reflection in action' als 'reflection on action'. 49

In de literatuur komt naar voren dat de tijd die voor het nabespreken moet worden gerekend minstens even lang, of zelfs langer duurt, dan de tijd die wordt genomen voor het spelen van het scenario. ${ }^{38}$ Het nabespreken van het scenario moet bovendien in een veilig klimaat gebeuren, waarin de participanten en de instructeur elkaar positief benaderen als het ware een 'social practice', zodat het zelfvertrouwen van de participanten niet wordt geschaad. ${ }^{114145}$ Kritiek op het handelen en feedback moeten worden gebracht in een constructieve, niet veroordelende atmosfeer. ${ }^{38}$ Het veilige klimaat kan door de instructeur al worden geschapen bij het voorbespreken, door afspraken te maken over vertrouwelijkheid van de trainingen en door de participanten goed voor te lichten over doelstellingen, inhouden en status van de training.

Er moet bij de debriefing opnieuw rekening gehouden worden met de karakteristieken van het team en de verschillende leerstijlen en niveaus van de participanten. Simulatie kan een grote impact hebben op de deelnemers. Het is dan ook van belang bij de start van de debriefing te weten wat de perceptie van de participan- ten is over de wijze waarop de simulatie is verlopen en hoe zij hun eigen bijdrage hebben ervaren. ${ }^{47}$ Daarnaast is het van belang om de feedback af te stemmen op de individuele participanten. Ook is belangrijk het aantal leerpunten realistisch te houden, waarbij twee tot drie leerpunten per persoon vaak maximaal haalbaar zijn. ${ }^{41}$ Belangrijk is dat participanten tijdens de debriefing niet alleen hun kennis verrijken ten aanzien van het uitgevoerde scenario, maar ook leren na te denken over hoe ze het geleerde kunnen implementeren in hun dagelijkse werk. ${ }^{45-46}$

Tijdens het nabespreken wordt een beschrijving gegeven van wat zich heeft afgespeeld tijdens het scenario. Dit wordt door de groep geanalyseerd, bijvoorbeeld door middel van een gedetailleerde discussie over eigen ervaringen. ${ }^{38}$ De voors en tegens van de genomen besluiten kunnen worden afgewogen, dit met betrekking tot zowel de technische als de niettechnische vaardigheden. Daarna kunnen toelichtingen en aanvullingen worden gegeven op hetgeen zich heeft afgespeeld. De instructeur kan hierbij toelichtingen geven aan de hand van de lijst met teamcompetenties. Er kunnen vervolgens leerdoelen geformuleerd worden ten aanzien van de onderdelen waar verbetering kan worden bereikt. ${ }^{45-46}$

Bij het nabespreken kan de instructeur een dominante rol innemen of op de achtergrond blijven. Het leereffect blijkt het grootst als de instructeur meer vanuit de groep zelf laat komen. ${ }^{45} 47$ De lijnen worden wel uitgezet, maar participanten beschrijven hun eigen proces en de leerdoelen die naar voren komen in het scenario. De instructeur kan hierbij commentaar geven en open vragen stellen om het proces te begeleiden. In de praktijk blijkt dat instructeurs teveel zelf het woord hebben, geen stiltes laten vallen en te veel gesloten vragen stellen. ${ }^{47}$ 
Bij het nabespreken kan mogelijk gebruik worden gemaakt van videomateriaal dat is gemaakt tijdens het scenario. Fragmenten kunnen dan worden teruggekeken om vanuit een ander perspectief te kijken naar de eigen verrichtingen. Met behulp van het videomateriaal kunnen alternatieven worden besproken. Niet alle studies laten een duidelijke positieve invloed zien van het gebruik van videomateriaal. ${ }^{47}$ Juist de wijze waarop de debriefing wordt gevoerd, is bepalend of video opnamen nuttig zijn of niet. ${ }^{50}$ Shapiro et al. pleiten bijvoorbeeld voor het ontwerpen van een concreet debriefing protocol. ${ }^{43} \mathrm{Zo}$ is gewaarborgd op welke teamvaardigheden feedback wordt gegeven tijdens de debriefing. Dit kan echter wel een probleem zijn bij videogeleide debriefing, omdat de volgorde bij zo'n debriefing vaak aan de hand van de video-opname wordt bepaald en niet zozeer aan de hand van een vooraf opgesteld debriefing protocol. Tabel 4 geeft een overzicht van tips voor de debriefing. ${ }^{41}$

\section{De rol van de instructeur(s)}

In de simulatie teamtraining is de instructeur vooral een begeleider, een 'facilitator'. Hij of zij begeleidt het leerproces van de participanten in de training en probeert daarbij zoveel mogelijk uit de groep zelf te halen.

De instructeur heeft zowel een belangrijke taak in de voorbereiding als tijdens de uitvoering van het scenario en in de nabespreking en afsluiting van de training. ${ }^{38-39}$ De instructeur denkt vaak zelf het scenario uit. ${ }^{38}$ Hij zorgt ook dat alles klaarstaat voor de training zelf. Voor het doorlopen van het scenario bereidt hij de participanten voor op de training. Hij zorgt dat de casus, de rol van de participanten en de omgeving van de simulatie helder zijn. Hij geeft de verhouding tot het onderwijsprogramma weer, de relatie met de leerdoe- len en zorgt bovendien voor een veilig leerklimaat. ${ }^{1141}$ Daarnaast is de instructeur bij VARS soms ook nog cameraman en technicus, waarnaast hij ook inhoudelijk het scenario moet volgen om aanwijzingen die gebruikt kunnen worden voor de debriefing te noteren.

Het debriefen bij medische teams vraagt niet enkel om klinisch inhoudelijke expertise, maar ook om goede observatievaardigheden en het vermogen om gerichte feedback te geven, op zowel individueel als teamniveau. ${ }^{39}$ Een instructeur moet klinische situaties kunnen analyseren, geschikte leermomenten in een scenario kunnen identificeren, factoren die bijdragen tot een eventuele uitkomst kunnen herkennen en effectieve strategieën in een scenario kunnen bekrachtigen of alternatieve gedragingen kunnen aandragen.

In de nabespreking is de instructeur onder andere verantwoordelijk voor het leiden van de discussie en voor het creëren van een veilige situatie. De instructeur kan problemen laten analyseren, technische en niet-technische vaardigheden beschrijven en alternatieve strategieën laten formuleren door de participanten. ${ }^{39} \mathrm{Bij}$ het afsluiten kan de instructeur zelf een goede samenvatting geven en vragen beantwoorden van de participanten. Dit vraagt nogal wat van een instructeur. Deze moet dan ook zelf goed geschoold zijn en voorbereid op zijn of haar taak. ${ }^{38}$ Zo dient de instructeur ook te beschikken over goede didactische vaardigheden om te kunnen differentiëren tussen teamleden die niet actief willen zijn tijdens de debriefing en zij die de kans niet krijgen om actief mee te doen. ${ }^{45-46}$ Heres en Vermeulen raden aan om de instructeurs te laten scholen middels cursussen van EUSIM. $^{7}$ (zie hiervoor www.eusim.org).

Dieckmann et al. pleit ervoor de vaardigheden van instructeurs regelmatig te laten evalueren door andere instructeurs, 
Tabel 4. Tips voor de debriefing. ${ }^{41}$

1. De debriefing moet diagnostiserend zijn

a. de debriefing richt zich op beslissende punten in kritische situaties,

b. het debriefen moet een zich herhalend proces zijn, om bijvoorbeeld teamworkvaardigheden structureel te verbeteren.

2. Zorg voor een ondersteunende leeromgeving voor de debriefing
a. zorg voor voldoende tijd voor de debriefing,
b. zorg voor ondersteuning vanuit de afdeling; dit motiveert om het geleerde om te zetten in de prak- tijk,
c. zorg voor een open cultuur, waarin iedereen eerlijk op elkaars handelen kan en mag reageren.

3. Moedig teamleiders en teamleden aan om te letten op teamworkprocessen tijdens de simulatie/praktijksituatie

a. dit lukt beter als vooraf de teamworkvaardigheden geïntroduceerd zijn, maar men moet ook rekening houden met de hoeveel die een individu echt meteen kan verwerken!

4. School teamleiders in het geven van debriefings, zodat zij de volgende vaardigheden bezitten
a. het programma van de debriefing kunnen vaststellen,
b. doelen van de debriefing kunnen vaststellen (eventueel aan de hand van voorgaande debriefingen),
c. teamleden kunnen aanmoedigen te participeren in een training,
d. de debriefing kunnen richten op bijvoorbeeld teamwork vaardigheden en teamprocessen.

5. Zorg voor een veilig en 'goed' gevoel tijdens de debriefing

a. creëer een veilig klimaat. Hierbij kan men letten op vertrouwelijkheid van alle besproken zaken.

6. Richt je op een paar kritische prestatieproblemen in het proces van debriefing

a. tijd is kostbaar; het is beter een paar zaken goed te bespreken, dan alles half.

7. Benoem en beschrijf de specifieke teamworkinteracties en processen die betrokken zijn in het presteren van het team:

a. hierdoor leren teamleden bewust van hetgeen zij doen en kunnen later ook bewust sturen.

8. Ondersteun de feedback met objectieve prestatie-indicatoren

a. specifieke voorbeelden, bijvoorbeeld videobeelden, zorgen voor betere acceptatie,

b. feedback kan beter gelinked worden aan concreet gedrag, zodat dit aangepast of juist behouden kan worden in de toekomst.

9. Feedback over uitkomsten moet minder vaak en later in de debriefing aan bod komen dan feedback over het proces:

a. processen geven concrete punten waarop het handelen aangepast kan worden.

10. Zorg zowel voor feedback aan individuen als feedback aan het team als geheel en herken wanneer dit het meest gepast is

11. Zorg voor een korte periode tussen het uitvoeren van de simulatie/praktijksituatie en het geven van feedback

a. bij een directe debriefing blijft de link tussen gedrag en uitkomsten blijft beter bestaan.

12. Leg getrokken conclusies en gestelde doelstellingen vast, zodat deze gebruikt kunnen worden voor toekomstige trainingen/debriefingen

a. dit is het begin van een doorgaande leerlijn en zorgt voor betere transfer naar de praktijk. 
met oog op de ontwikkeling van de instructeurs. ${ }^{45}$ 'Reflection in action' en 'reflection on action' lijken hier uitermate voor geschikt. Eigenlijk is het takenpakket van een instructeur zo complex, dat er twee instructeurs nodig zijn om een training écht goed te kunnen begeleiden.

\section{De plaats van simulatie in de opleiding}

Onderzoek heeft aangetoond dat transfer van geleerde gedragingen vanuit trainingen naar de praktijk niet altijd plaatsvindt. ${ }^{11}$ Hiertoe kunnen lessen geleerd worden van de luchtvaart, waar men veel meer ervaring heeft met de CRM training en de transfer naar de praktijk. Een aantal dingen lijkt erg belangrijk:

- Het creëren en onderhouden van goede teams vergt planning en voorbereiding. Er moet geïnvesteerd worden in nieuwe teams.

- Factoren vóór, gedurende en na de training kunnen gevolgen hebben op de effectiviteit van de teamtraining.

- Teams moeten zowel getraind worden in hun taken (technische vaardigheden) als in teamworkvaardigheden (niettechnische vaardigheden).

- Maak gebruik van bestaande hulpmiddelen voor de creatie, implementatie en evaluatie van teamtraining.

- Teams zijn complex; er zal nog veel moeten worden bijgeleerd over het effectiever maken van teams.

Teamtraining wordt nog niet systematisch ingezet in het curriculum. ${ }^{13} \mathrm{Om}$ echt effectief te zijn, moeten deze trainingen wel worden geïntegreerd in het totaalprogramma van de opleiding en in de praktijk op de dagelijkse werkvloer. ${ }^{39}$ Hoe dit het beste kan is nog niet echt bekend. De literatuur geeft wel aan dat wanneer de training regelmatig en op het goede moment wordt gegeven, het leerrendement het hoogst is. ${ }^{36}$ In het artikel van Blum et al. werd bijvoorbeeld door participanten aangegeven dat zij graag zouden zien dat de training iedere 18 tot 24 maanden wordt herhaald. ${ }^{51}$

Daarnaast mag simulatie geen vervanging zijn van het leren in de klinische setting, maar moet het een aanvulling zijn hierop. ${ }^{35}$ Simulatietraining is geen doel op zich maar een middel, dat kan worden ingezet over het gehele continue spectrum van de medische opleiding. ${ }^{28}$

\section{Beoordeling}

Bij de beoordeling van teamprestaties is het van belang verschil te maken tussen een formatieve beoordeling en een summatieve beoordeling. ${ }^{52}$ Een formatieve beoordeling in teamtrainingen is gericht op het geven van feedback en doelt op het verbeteren van processen en het functioneren van individu en team. Een summatieve beoordeling velt een oordeel over het niveau van het functioneren van het team, waarbij het primaire doel niet ligt bij het geven van feedback. De keuze formatief of summatief is bepalend voor de wijze waarop een teamtraining wordt vormgegeven. Bij simulatie teamtrainingen gaat het doorgaans over het willen verbeteren van teamprestaties, waarbij door middel van feedback in de debriefing wordt gereflecteerd op het handelen en er zo actief wordt geleerd. ${ }^{17}$ Simulatie teamtrainingen bieden juist ruimte om dingen uit te proberen en fouten te maken.

Hier passen formatieve beoordelingen het beste bij.

Wil men consequenties verbinden aan een simulatietraining in de zin van een 'go/no go' beslissing (summatieve beoordeling) dan stelt dat ook eisen aan de kwaliteit (validiteit en betrouwbaarheid) van de beoordeling. Kim et al. hebben een checklist ontwikkeld waarbij ook criteria zijn opgenomen (Bijlage 4). ${ }^{1}$ 
Tabel 5. De vier niveaus van Kirkpatrick (1998) voor het evaluaeren van trainingen. ${ }^{55}$

\section{Niveau 1: Evaluatie van reacties}

Een evaluatie om de perceptie van de deelnemers omtrent de opleiding te leren kennen. Hebben de deelnemers de training als positief ervaren? Was de behandelde stof relevant voor hun werk?

Uitvoering: deze evaluatie moet geschieden voordat aan niveau 2 kan worden begonnen. Hoewel een positieve reactie op niveau 1 niet garandeert dat men iets heeft geleerd, betekent een negatieve reactie een absolute vermindering van de kans dat men iets heeft opgestoken. Meten kan door middel van een vragenlijst, of bijvoorbeeld door mondelinge feedback.

\section{Niveau 2: Evaluatie van het leren}

Een evaluatie om te bepalen of de deelnemers de inhoud van de cursus tot zich hebben genomen, geleerd hebben. Is men vooruitgegaan in vaardigheden, in kennis of is er sprake van veranderd gedrag?

Uitvoering: het meten op dit niveau is moeilijker en neemt meer tijd in beslag. Het best is als cursisten een pretest doen, de training volgen en vervolgens een posttest. Op die wijze kan een duidelijk beeld van de ontwikkeling worden verkregen.

\section{Niveau 3: Evaluatie van het gedrag}

Een evaluatie om te bepalen in welke mate de cursist de nieuw aangeleerde vaardigheden en/of kennis in zijn baan gebruikt. Kunnen ze het geleerde gebruiken in de dagelijkse praktijk? En hoe doen ze dat dan? Uitvoering: het blijkt lastig om echt in de praktijk te meten wat men anders doet dan voorheen. Hoe, hoe vaak en wanneer er wordt geëvalueerd, zijn daarbij de belangrijkste vragen.

\section{Niveau 4: Evaluatie van het resultaat}

Een evaluatie van de impact die de training heeft op het functioneren van het bedrijf. Het gaat hierbij bijvoorbeeld om een verbetering van de kwaliteit van zorg door een trainingsprogramma, maar bijvoorbeeld ook meer efficiëntie in zorgprocessen, waardoor geld wordt gespaard.

Uitvoering: deze evaluatie is zeer moeilijk uit te voeren. Het is lastig om bedrijfsbrede verbeteringen terug te voeren op trainingsprogramma's, omdat er meestal meer factoren van invloed zijn op het goed draaien van de organisatie.

Het meten van veranderingen in de praktijk blijkt nog zeer lastig. Instrumenten als een Korte Praktijk Beoordeling (KPB) en Multi Source Feedback (MSF), eventueel in een aangepaste versie, zouden ingezet kunnen worden om te bepalen of na trainingen het handelen van een arts in opleiding tot specialist (aios) is veranderd ten opzichte van voorheen. ${ }^{54-55}$

Het doel van simulatie teamtrainingen is dat uiteindelijk de teamprocessen en het teamfunctioneren op de werkvloer geoptimaliseerd worden. Bij de implementatie van een onderwijsmethode moet dan ook aandacht besteed worden aan de effectivi- teit en efficiëntie van deze methode in het bereiken van haar doelstellingen. Vandaar dat een evaluatie ook hoort bij het ontwerpen van een onderwijsmethode. ${ }^{13} 21$

Kirkpatrick heeft een model ontwikkeld dat gebruikt kan worden voor het evalueren van onderwijs- en trainingsprogramma's. ${ }^{56}$ Daarin beschrijft hij vier niveaus waarop je een training kunt evalueren. Het laagste niveau heeft te maken met de reacties van de deelnemers. Een niveau hoger wordt gekeken naar wat de deelnemers van een training hebben geleerd. De twee hoogste niveaus kijken naar hoe het geleerde zich vertaalt naar het werk op de 
werkvloer, waarbij het ene kijkt naar het werkgedrag en het andere naar de bedrijfsresultaten (Tabel 5).

In de praktijk wordt meestal enkel op de laagste twee niveaus, reactie en leren, geëvalueerd. ${ }^{132157} \mathrm{Om}$ écht naar de effectiviteit van trainingsprogramma's te kijken, dat wil zeggen dat de werkprocessen en -uitkomsten positief worden beïnvloed, moet er ook op de andere twee niveaus geëvalueerd worden. Hier is in de medische literatuur nog weinig over geschreven. De complexiteit van teamprestaties blijkt een grote uitdaging te vormen voor het meten van deze teamprestaties. ${ }^{57} \mathrm{Er}$ moeten nog meer en nog betere evaluatiemethoden ontwikkeld worden om een goede bepaling van de effectiviteit te kunnen doen. ${ }^{21} 4357$ Gelukkig worden deze initiatieven opgepikt. Zo hebben Loughry, Ohland en Moore een instrument ontwikkeld voor peer-assessment en zelfevaluatie van effectiviteit van teamleden en geven Rosen et al. tips over de wijze waarop deze complexe teamvaardigheden het best op hun effectiviteit beoordeeld kunnen worden. ${ }^{57-58}$

\section{Tot slot}

Met behulp van simulatieonderwijs kunnen technische en niet-technische medische vaardigheden samen worden getraind in een veilige omgeving. De efficiëntie en de veiligheid van het medische systeem worden hierdoor verbeterd.

De volgende uitdagingen liggen echter nog te wachten.

- De vorming van een theoretisch model omtrent teamprestaties in de gezondheidszorg.

- Het gebruik van bewezen instructiestrategieën als basis voor de teamtrainingsprogramma's.

- De verdere aanpassing van deze teamtrainingsstrategieën aan specifieke behoeften uit de gezondheidszorg.
- De inbedding van teamtrainingen in de gehele gezondheidszorg en in de gehele professionele training.

- Een grote investering in simulatie teamtrainingen. Het gaat hierbij om geschikte ruimtelijke voorzieningen, simulatoren, adequate organisatie, technische en logistieke ondersteuning. Daarbij zijn goede instructeurs cruciaal voor een goede training. Dit betekent een investering in het opbouwen en in stand houden van een groep instructeurs, een goede aansturing hiervan, deskundigheidsbevordering etc.

\section{Literatuur}

1. Kim J, Neilipovitz D, Cardinal P, Chiu M. A comparison of global rating scale and checklist scores in the validation of an evaluation tool to assess performance in the resuscitation of critically ill patients during simulated emergencies (abbreviated as "CRM simulator study IB"). Simul Healthc 2009;4(1):6-16.

2. Flin R, Maran N. Identifying and training nontechnical skills for teams in acute medicine. Qual Saf Health Care 2004 October;13 Suppl 1:i80-i84.

3. Yule S, Flin R, Paterson-Brown S, Maran N, Rowley D. Development of a rating system for surgeons' non-technical skills. Med Educ 2006 November;40(11):1098-104.

4. Thomas CM, Bertram E, Johnson D. The SBAR communication technique: teaching nursing students professional communication skills. Nurse Educ 2009 July;34(4):176-80.

5. Bleker O.P, Cate ThJ ten, Holdrinet R.S.G. De algemene competenties van de medisch specialist in de toekomst. Tijdschrift vor Medisch Onderwijs 2004;23(1):4-14.

6. Frank JR, Danoff D. The CanMEDS initiative: implementing an outcomes-based framework of physician competencies. Med Teach 2007 September;29(7):642-7.

7. Heres M, Vermeulen H. Simulatie teamtraining acute gezondheidszorg en verloskunde. Apeldoorn: Garant; 2010.

8. Kohn L.Y, Corrigan J.M, Donaldson M.S. To Err is Human: Building a Safer Health System. Washington DC: National Academic Press; 2000.

9. Wilford A, Doyle TJ. Integrating simulation training into the nursing curriculum. Br J Nurs 2006 September 28;15(17):926-30 
10. Awad SS, Fagan SP, Bellows $\mathrm{C}$ et al. Bridging the communication gap in the operating room with medical team training. Am J Surg 2005 November;190(5):770-4.

11. Burke CS, Salas E, Wilson-Donnelly K, Priest H. How to turn a team of experts into an expert medical team: guidance from the aviation and military communities. Qual Saf Health Care 2004 October;13 Suppl 1:i96-104.

12. Cherry RA, Ali J. Current concepts in simulationbased trauma education. J Trauma 2008 November;65(5):1186-93.

13. Ostergaard HT, Ostergaard D, Lippert A. Implementation of team training in medical education in Denmark. Qual Saf Health Care 2004 October;13 Suppl 1:i91-i95.

14. Baker DP, Day R, Salas E. Teamwork as an essential component of high-reliability organizations. Health Serv Res 2006 August;41(4 Pt 2):1576-98.

15. Firth-Cozens J. Cultures for improving patient safelty through learning: the role of teamwork. Quality in Health Care 2001;10(suppl II):ii26-ii31.

16. Salas E, Diazgranados D, Weaver SJ, King H. Does team training work? Principles for health care. Acad Emerg Med 2008 November;15(11): 1002-9.

17. Chakraborti C, Boonyasai RT, Wright SM, Kern DE. A systematic review of teamwork training interventions in medical student and resident education. J Gen Intern Med 2008 June;23(6):846-53.

18. Hamman WR. The complexity of team training: what we have learned from aviation and its applications to medicine. Qual Saf Health Care 2004 October;13 Suppl 1:i72-i79.

19. Leonard M, Graham S, Bonacum D. The human factor: the critical importance of effective teamwork and communication in providing safe care. Qual Saf Health Care 2004 October;13 Suppl 1:i85-i90.

20. Salas E, Rhodenizer L, Bowers CA. The design and delivery of crew resource management training: exploiting available resources. Hum Factors 2000;42(3):490-511.

21. Baker D.P, Gustafson S, Beaubien J, Salas E, Barach P. Medical Teamwork and Patient Safety: The Evidence-Based Relation. http://www airteams org/publications/MTT/AIR_Lit_Review pdf 2003.

22. Morey JC, Simon R, Jay GD et al. Error reduction and performance improvement in the emergency department through formal teamwork training: evaluation results of the MedTeams project. Health Serv Res 2002 December;37(6):1553-81.

23. Kurrek MM, Fish KJ. Anaesthesia crisis resource management training: an intimidating concept, a rewarding experience. Can J Anaesth 1996 May;43(5 Pt 1):430-4.

24. Gaba D.M, Howard S.K, Fish K.J, Smith B.E, Sowb Y.A. Simulation-based training in Anesthe- sia Crisis Resource Management. Simulation and Gaming 2001;32:175-93.

25. Healey AN, Undre S, Vincent CA. Developing observational measures of performance in surgical teams. Qual Saf Health Care 2004 October;13 Suppl 1:i33-i40.

26. Thomas EJ, Sexton JB, Helmreich RL. Translating teamwork behaviours from aviation to healthcare: development of behavioural markers for neonatal resuscitation. Qual Saf Health Care 2004 October;13 Suppl 1:i57-i64.

27. Fletcher G, Flin R, McGeorge P, Gravin R, Maran N, Patey R. Rating non-technical skills: developing a behavioural system for use in anesthesia. Cogn Tech Work 2004;6:165-71.

28. Yule S, Flin R, Maran N et al. Debriefing surgeons on non-technical skills. Cognition, Technology \& Work 2008;10(4):265-74.

29. Jankouskas T, Bush MC, Murray B et al. Crisis resource management: evaluating outcomes of a multidisciplinary team. Simul Healthc 2007;2(2):96-101.

30. VMSzorg. Communicatie tussen hulpverleners volgens het SBAR-proces. http:vmszorg nl/Documents/Tools_Extras/Veligheidssysteem/U532_co mSBAR_C p1_LR pdf 2009.

31. Scheele F, Teunissen P, Van LS et al. Introducing competency-based postgraduate medical education in the Netherlands. Med Teach 2008;30(3): 248-53.

32. Chou S, Cole G, McLaughlin K, Lockyer J. CanMEDS evaluation in Canadian postgraduate training programmes: tools used and programme director satisfaction. Med Educ 2008 September; 42(9):879-86.

33. Baker D.P, Gustafson S, Beaubien J.M, Salas J.M, Barach P. Medical Team Training Programs in Health Care. Advances in Patient Safety 2005; 4:253-67.

34. Beaubien JM, Baker DP. The use of simulation for training teamwork skills in health care: how low can you go? Qual Saf Health Care 2004 October;13 Suppl 1:i51-i56.

35. Maran NJ, Glavin RJ. Low- to high-fidelity simulation-a continuum of medical education? Med Educ 2003 November;37 Suppl 1:22-8.

36. Fox-Robichaud AE, Nimmo GR. Education and simulation techniques for improving reliability of care. Curr Opin Crit Care 2007 December;13(6): 737-41.

37. Issenberg SB, McGaghie WC, Petrusa ER, Lee GD, Scalese RJ. Features and uses of high-fidelity medical simulations that lead to effective learning: a BEME systematic review. Med Teach 2005 January;27(1):10-28.

38. Lighthall GK, Barr J, Howard SK et al. Use of a fully simulate $\mathrm{d}$ intensive care unit environment for critical event management training for in- 
ternal medicine residents. Crit Care Med 2003 October;31(10):2437-43.

39. Nimmo G.R, Shipey B, Fluit L. Intensive Care Training: a guide. Care of the Critically Ill 2008;24:1-5.

40. Reigeluth C.M. What is instructional-design theory and how is it changing? In: Reigeluth C.M, editor. Instructional- Design Theories and Models.Mahwah: NJ, LEA; 1999. p. 5-29.

41. Salas E, Klein C, King $\mathrm{H}$ et al. Debriefing medical teams: 12 evidence-based best practices and tips. Jt Comm J Qual Patient Saf 2008 September;34(9):518-27.

42. Bush MC, Jankouskas TS, Sinz EH, Rudy S, Henry J, Murray WB. A method for designing symmetrical simulation scenarios for evaluation of behavioral skills. Simul Healthc 2007;2(2):102-9.

43. Shapiro MJ, Gardner R, Godwin SA et al. Defining team performance for simulation-based training: methodology, metrics, and opportunities for emergency medicine. Acad Emerg Med 2008 November;15(11):1088-97.

44. Dominick P.G, Reilly R.R, McGourty J.W. The effects of peer feedback on team member behavior. Group \& Organization Management 1997;22(4): 508-20.

45. Dieckmann P, Molin FS, Lippert A, Ostergaard D. The art and science of debriefing in simulation: Ideal and practice. Med Teach 2009 July;31(7): e287-e294.

46. Dieckmann P. Using Simulations for education, training and research. Lengerich: Pabst Science; 2009.

47. Fanning RM, Gaba DM. The role of debriefing in simulation-based learning. Simul Healthc 2007; 2(2):115-25.

48. Kaufman DM. Applying educational theory in practice. BMJ 2003 January 25;326(7382):213-16.

49. Schon D. Educating the refelctive practitioner. San Fransisco: Jossey-Bass; 1987.

50. Savoldelli GL, Naik VN, Park J, Joo HS, Chow R, Hamstra SJ. Value of debriefing during simulated crisis management: oral versus video-assisted oral feedback. Anesthesiology 2006 August; 105(2):279-85.

51. Blum RH, Raemer DB, Carroll JS, Sunder N, Felstein DM, Cooper JB. Crisis resource management training for an anaesthesia faculty: a new approach to continuing education. Med Educ 2004 January;38(1):45-55.

52. Sadler D.R. Formative assessment and the design of instructional systems. Instructional Science 1989;18:119-44.

53. King, H.B. (n.d.) Team Strategies and Tools to Enhance Performance and Patient Safety. Verkregen op 15 februari 2009. http://www.ahrq.gov/ downloads/pub/advances2/vol3/Advances-King 1.pdf
54. Cate Th.J ten, Fluit C.R.M.G. Richtlijn korte praktijkbeoordeling. Tijdschrift voor Medisch Onderwijs 2010;29(5)suppl.4:105-134.

55. Horsman M, Cate Th.J. ten. Richtlijn multisource feedback voor de aios. Tijdschrift voor Medisch Onderwijs 2010;29(2),suppl.1:1-52.

56. Kirkpatrick D.L. Evaluating training programs: the four levels. San Fransisco: Berret-Koehler Publishers; 1998.

57. Rosen MA, Salas E, Wilson KA et al. Measuring team performance in simulation-based training: adopting best practices for healthcare. Simul Healthc 2008;3(1):33-41.

58. Loughry M.L, Ohland M.W, DeWayne Moore D. Development of a theory-based assessment of team member effectiveness. Critical Care Medicine 2007;31:2437-43.

De auteurs:

Drs. C.R.M.G. Fluit is arts/onderwijskundige en hoofd afdeling Evaluatie, Kwaliteit en Ontwikkeling (EKO) van het Onderwijsinstituut, UMC St Radboud Nijmegen.

Drs. T.P.F.M. Klaassen is onderwijskundige en werkzaam als onderzoeker bij de afdeling Evaluatie, Kwaliteit en Ontwikkeling van het Onderwijsinstituut, UMC St Radboud Nijmegen.

Correspondentieadres:

Drs. C.R.M.G. Fluit, afdeling Evaluatie, Kwaliteit en Ontwikkeling, 306 IWOO, UMC St Radboud Nijmegen, postbus 9101, 6500 HB Nijmegen. E-mail: c.fluit@iwoo.umcn.nl

Belangenconflict: geen gemeld

Financiële ondersteuning: geen gemeld 